\title{
\begin{tabular}{|l|}
\hline 葲 \\
\hline
\end{tabular} \\ スケーリング・ルートプレーニングの有効性 \\ に関する臨床的, 細菌学的研究
}

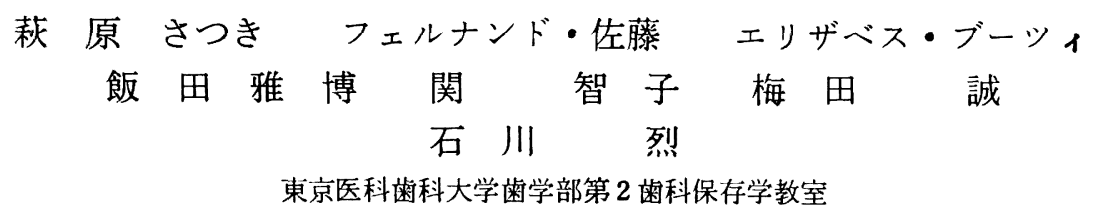

（1992年 2 月28日 受付）

\section{Clinical and Microbiological Study of Factors Determining Effective Scaling and Root Planing}

\author{
Satsuki Hagiwara, Ferando Sato, Elizabeth Boutsi \\ Masahiro Iida, Tomoko Seki, Makoto Umeda \\ and Isao Ishikawa
}

Department of Periodontology, Faculty of Dentistry, Tokyo Medical and Dental University

The aim of the present study was to monitor longitudinally the clinical and microbiological parameters after root debridement in order to determine the factors affecting successful and unsuccessful results. Nine patients with moderate and severe periodontitis participated. Four sites of single root with over $5-\mathrm{mm}$ periodontal pockets in each quadrant were selected. The oral hygiene was controlled 'in all patients, then root debridement was performed without anesthesia at the three sites of the quadrants every two weeks during eight weeks. The clinical parameters consisted of plaque index, gingival index, probing depth, clinical attachment level, bleeding on probing, tooth mobility and the value of gingival crevicullar fluid (GCF). The microbiological parameters such as percentages of cocci, motile rods, non-motile rods and spirochetes and the number of microorganisms were examined and the percentages of black pigmented Bacteroides (BPB) and Actinobaccilus actinomycetemcomitans as well as the number of anaerobic colonies were counted. The results demonstrated that a reduction in the probing depth was observed in all sites except four. The successful sites clinically showed a decrease of the probing depth and GCF value and, microbiologically, reduced percentages of the spirochetes and BPB. The results indicated that the decrease of the probing depth and GCF under 50 Periotoron units in coincidence with the bacterial reduction can be used to determine the successful response of root debridement.

\section{I. 緒言}

歯周炎の発症と進行には, いくつかの菌周疾患 関連菌と呼ばれるプラーク中のグラム陰性桿菌が
関与している ${ }^{1)}$ 。米周治療の目的の一つは, 歯周 疾患関連菌を含むプラークを除去し, 再びプラー クが付着するのをコントロールすることである。 歯周ポケット内のプラークコントロールは, ス 
ケーリング・ルートプレーニングにより機械的に 行われるのが一般的である。しかし，柬周ポケッ トが深い場合, 歯根の解剖学的形態が複雑な場 合，米列異常があるような場合には，技術的に器 具操作が難しく霜周ポケット底部の歯石やプラー クを完全に除去することは困難である ${ }^{2,3)}$ 。これ らの理由によりスケーリング・ルートプレーニン グの有効性について術後の観察を行らと, 歯周組 織が健康な状態に改善されることも多く認められ るが，そのまま病変が残ってしまらこともある。 この相反する状態は比較的早い時期のらちにどの ような因子で判別できるかという点については， 充分な報告がこれまで行われていない。歯周治療 の効果を上げるために，スケーリング・ルートプ レーニングを行った後, 治湶する場合とそらでな い場合を識別する臨休的, 細菌学的要因を捕ら之 ることは重要である。

そこで今回私達は, スケーリング・ルートフレ ーニングを徹底的に行った場合の，有効性を判断 しうる要因を明らかにするために, 臨床的および 細菌学的に研究を行った。

\section{II. 材料と方法}

\section{1. 被験者および被験㐘}

被験者としては, 東京医科菌科大学歯学部附属 病院に来院した中等度から重度に進行した歯周炎 患者 9 名, 男性 2 名, 女性 7 名, 年齢 $27 \sim 49$ 歳 （平均年路39.1藏）を選択した。全身的健康状態 は良好で，6力月間抗生物質を服用せず，歯周治 療を受けていない者を対象とした。被験部位とし ては, 上下顎左右 4 部位に分かれて存在する 5 $\mathrm{mm}$ 以上の歯周ポケットをもつ 4 本の単根雨とし た。

\section{2. 試験方法}

実験のスケジュールとしては, 最初にすべての 患者にブラッシングによるプラークコントロール 指導を行った。 2 週ごとに 4 回指導し, 被験部位 の Plaque Index (PlI) $)^{4)}$ がほぼ0になったこと を確認してスケーリング・ルートプレーニングを 2 週ごとに 4 回繰り返して行った。超音波スケー
ラーにより全顎的に歯肉縁上のスケーリングを行 った後，無麻酰下で被験部位および両隣在歯に対 して,グレーシー型のスケーラーを用いて歯周ポ ケット内露出歯根面の debridement を行った。 各被験者の 4 歯のうち，任意に選択した 3 歯を実 験歯とし，他の 1 歯を対照歯とした。処置後， 2 週ごとに 3 力月間, 予後を観察した。臨床上の処 置に関しては, 一人の検者が行っだ。

\section{3. 臨床パラメーター}

臨床所見に用いたパラメーターとしては, Plaque Index (PlI $)^{4)}$, Gingival Index $(\mathrm{GI})^{5)}$, probing pocket depth (PPD), Bleeding on probing6), attachment level (AL), 歯の動摇度 を選んだ。さらに歯周ポケット内の炎症症状を表 寸歯肉溝浸出液量 (Gingival Crevicular Fluid, GCF）をハルコ社製ペリオトロン6000を用いて測 定した。测定は, ペリオペーパーを歯周ポケット 内に静かに抵抗を感じる所まで挿入し，5秒後に 測定する方法で行い，初回の測定值を菓却し， 3 回の測定値の平均を用いた。

\section{4. 細菌学的パラメーター}

3 本の滅菌ペーパーポイントを用いて歯周ポケ ット内のサンプリングを行い, 得られたサンプル を $2 \mathrm{~m} l$ の減菌還元輪送培地に入れて, ボルテッ クスミキサーで30秒間掜找した後, $5 \mu l$ を暗視 野顕微鏡下での観察に用い, $50 \mu l$ を $10^{-1} \sim 10^{-4}$ まで連続的に10倍希釈して培養に用いた。

1）暗視野顕微鏡下での形態学的観察は, Listgarten \& Hellden らの基準》に従って行い, cocci (球状菌), rods (桿状菌), motile rods (運 動性桿菌), spirochetes (スピロヘータ)の 4 種類 の細菌の占める比率とサンプル $1 \mathrm{~m} l$ 当りの総菌 数について計算した。

2）得られたサンプルを培養し，黒色色素産生 性菌 (BPB) および Actinobacillus actinomysetemcomitans (A. a.) について調べた。BPB につい ては, 血液寒天培地 (Trypticase soy agar (BBL Microbiological Systems \& Co., Cockeysville, MD, USA) に馬血液 ( $5 \%)$, hemin ( 5 $\mu \mathrm{g} / \mathrm{m} l)$, vitamin $\mathrm{K} 1(0.1 \mu \mathrm{g} / \mathrm{m} l)$ を含む)を用 
表 1 スケーリング・ルートプレーニング後の予後良好例と非良好例の比較

\begin{tabular}{|c|c|c|c|c|c|}
\hline & & -8 週 & 0 週 & 2 週 & 12週 \\
\hline $\begin{array}{l}\text { GCF } \\
\text { (periotron units) }\end{array}$ & $\begin{array}{l}\text { 良 好 例 } \\
\text { 非良好例 }\end{array}$ & $\begin{array}{l}103.9(23.7) \text { । }^{*} \\
134.2(30.0) \text { - }\end{array}$ & $\begin{array}{r}93.7(29.3)-1 \\
130.7(29.1){ }^{* *}\end{array}$ & $\begin{array}{l}43.3(22.8) * * \text { 一 } \\
87.6(38.0) * * \text { - }\end{array}$ & $\begin{array}{l}29.5(13.7) * * \text { 一 } \\
90.6(22.5) * * \text { I }^{*}\end{array}$ \\
\hline $\begin{array}{l}\text { probing depth } \\
(\mathrm{mm})\end{array}$ & $\begin{array}{l}\text { 良 好 例 } \\
\text { 非良好例 }\end{array}$ & $\begin{array}{l}5.3(0.6) \\
6.1(1.2)\end{array}$ & $\begin{array}{l}5.1(0.8)-1 \\
6.1(1.1)-*\end{array}$ & $\begin{array}{l}3.6(0.6)^{* *-} \\
4.8(1.1)^{*}\end{array}$ & $\begin{array}{l}2.7(0.5) * *-1 \\
4.5(1.1) * * *_{1}^{*}\end{array}$ \\
\hline spirochetes & $\begin{array}{l}\text { 良 好 例 } \\
\text { 非良好例 }\end{array}$ & $\begin{array}{r}5.4(4.6)- \\
13.7(10.5){ }^{* *}\end{array}$ & $\begin{array}{r}4.1(4.2)- \\
16.9(15.5)-{ }^{* *}\end{array}$ & $\begin{array}{l}0.3(0.6)^{* *} \\
2.3(3.2)^{* *}\end{array}$ & $\begin{array}{l}0.3(0.9) * * \\
2.2(2.3) * *\end{array}$ \\
\hline$(\%)$ & $\begin{array}{l}\text { 良 好 例 } \\
\text { 非良好例 }\end{array}$ & $\begin{array}{ll}34.1 & (14.4) \\
31.1 & (19.4)\end{array}$ & $\begin{array}{l}19.5(16.4) \\
16.0(15.5)\end{array}$ & $\begin{array}{r}5.0(5.1)^{* *} \\
15.8(15.5)^{* *}\end{array}$ & $\begin{array}{l}1.1(2.2) * * \\
17.8(13.6)\end{array}$ \\
\hline
\end{tabular}

良好 例: $\mathrm{GCF}<50(\mathrm{n}=14)$

非良好例 : GCF $\geqq 50(n=13)$
平均値 (標準偏差)

$*: \mathrm{p}<0.05, * *: \mathrm{p}<0.01$
い, 嫌気性培養ジャ一 (平山製作所製) 中で嫌気 的条件下で 7 日間培養した。培養後, カウントし た BPBのコロニーの比率とコロニーの総数を求 めた。A. a.については TSBV 寒天培地 (Trypticase soy agar, Yeast extract (BBL Microbiological Systems \& Co., Cockeysville, MD, USA, Yeast extract (DIFCO) に馬血清 (10\%), Bacitracin $(75 \mu \mathrm{g} / \mathrm{m} l)$, Vancomycin $(5 \mu l / \mathrm{m} l)$ を含む）を用い， $5 \% \mathrm{CO}_{2}$ を含む好気的条件下 で 7 日間培養した。培養後，A. a. のコロニーの 出現率について調べた。

\section{5. 統計処理}

各臨木および細菌学的パラメーターの経時的変 化の有意差の検定は, Wilcoxon の符号付き順位 検定， 1 標本 $\mathrm{t}$ 検定を用い，群間比較については Wilcoxon の順位和検定により統計処理を行っ た。

\section{III. 結果}

\section{1. probing pocket depth の変化}

全被験部位 27 部位のうち, 処置後 3 力月目に probing depthの減少がみられたのは23部位であ った。他の 4 部位の probing pocket depth は, 処置前と処置後において変化がみられなかった。

\section{2. 臨床的および細菌学的指標の経時的变化による} グループ分け
瀶林的パラメーターのうち, GCF 量, probing pocket depth の二つの因子, 細菌学的パラメータ 一のらち spirochetes, BPBの比率の二つの因子に 注目したところ, GCF 量および probing pocket depth が減少し, spirochetes と BPBの比率の減 少量が大きい部位と, これらの各パラメーターの 測定值の減少量が前者よりも小さな部位の二つの グループに分かれた。そこで処置後12週で, GCF 量および probing pocket depth の減少がみら れ, 細菌学的には spirochetes の比率は $3 \%$ 以下 であり，BPB の比率は10\%以下であるといら四 つの条件をすべて満たす部位を治癒の良好であっ たグループ(予後良好群)，その他の部位を治瘺の 良好でなかったグループ（予後不良群）とした。 この二つのグループは, 臨床的には GCF 量が50 ペリオトロン・ユニットで分けられた。

二つのグループの四つのパラメーターの変化に ついてスケーリング・ルートプレーニング前ー 8 週, 処置開始時 0 週, 処置終了後 2 週, および 12 週の時点での平均値を表 1 に示す。処置開始時 0 週の時点での各パラメーターの測定值の平均值に ついてはつのグループ間で GCF 量, spirochetes の比率については有意差がみられたが, probing pocket depth および BPB の比率については, 有意差はみられなかった。処置終了後 2 週, 12 週 では BPB の比率を除くすべてのパラメーターに 


\section{GINGIVAL CREVICULAR FLUID}
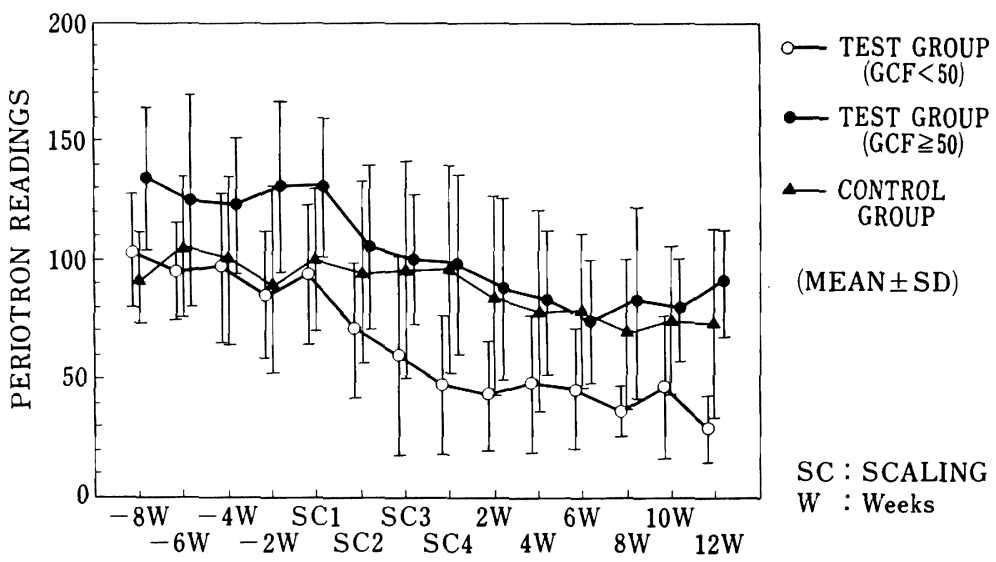

図 1 GCF 量の経時的变化

PROBING DEPTH

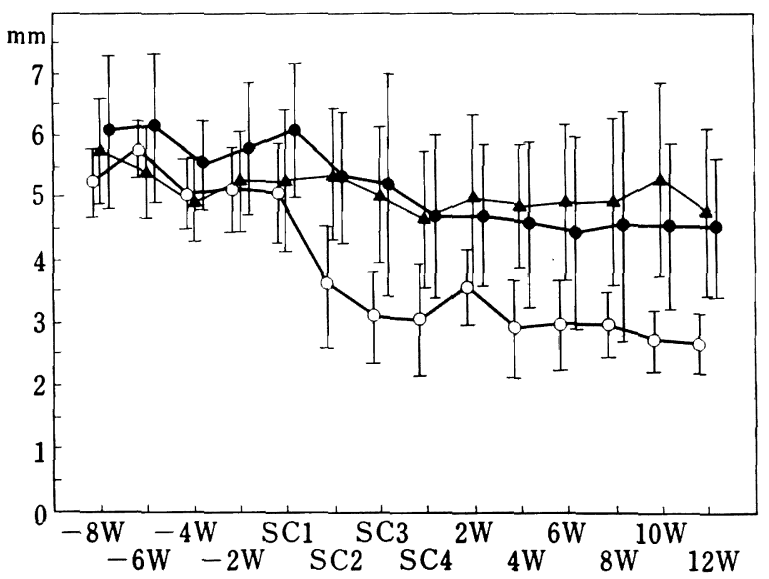

$$
\begin{gathered}
\text { - TEST GROUP } \\
(\text { GCF }<50) \\
- \text { TEST GROUP } \\
(\text { GCF } \geqq 50) \\
- \text { CONTROL } \\
\text { GROUP } \\
(\text { MEAN } \pm \text { SD })
\end{gathered}
$$

SC : SCALING

$\mathrm{W}:$ Weeks

因 2 probing depth の経時的変化

ついては， 0 週の時点での平均值と比較してスケ ーリング・ルートプレーニング後, 経時的に有意 の減少がみられた。特に GCF 量について注目す ると, 処置終了後 2 週目ですでに 50 ペリオトロン ユニット以下の平均値を示している。

\section{GCF 量の経時的変化}

図 1 に GCF 量の経時的変化を示す。白丸印は 12週の時点で良好な治癒を示したグループ（予 後良好群), 黒丸印は良好な治瘺を示さなかった グループ (予後不良群), 三角印はコントロール

\section{グループを示す。}

$\mathrm{GCF}$ 量はスケーリング・ルートプレーニング 開始時 0 週の時点で, 実験群の平均值は予後良好 群 93.7, 予後不良群 130.7 であり，予後不良群は Baseline の段階での GCF 量は高かった。どち らのグループも Baseline から処置後12週までに 経時的に有意の減少を示した。予後良好群では処 置後 2 週目の時点ですでに 43.3 と 50 ペリオトロ ン・ユニット以下の平均値を示したが，予後不良 群では処置後 2 週目に抋いても87.6，12週後では 


\section{SPIROCHETES}

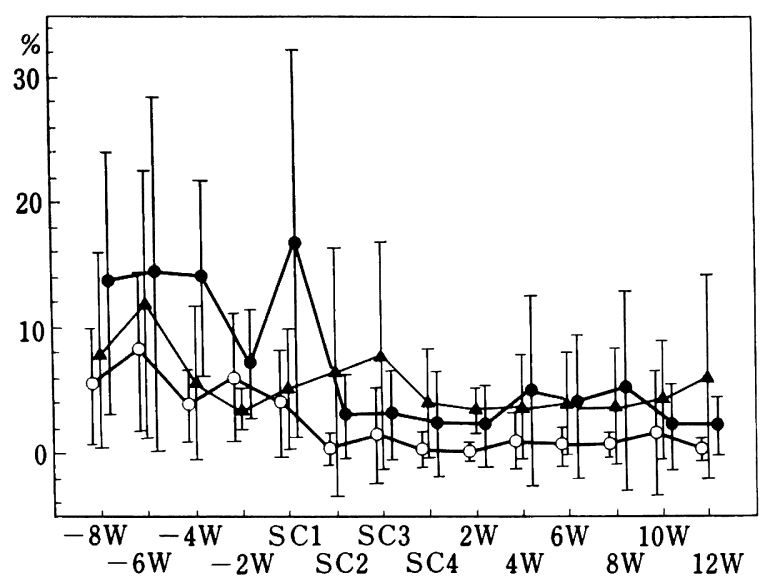

$$
\begin{aligned}
& - \text { TEST GROUP } \\
& (\text { GCF }<50) \\
& - \text { TEST GROUP } \\
& (\text { GCF } \geqq 50) \\
& \sim \text { CONTROL } \\
& \text { GROUP } \\
& (\text { MEAN } \pm \text { SD }) \\
& \\
& \text { SC : SCALING } \\
& \text { W : Weeks }
\end{aligned}
$$

図 3 spirochetes の比率の経時的変化

\section{BLACK PIGMENTED BACTEROIDES}

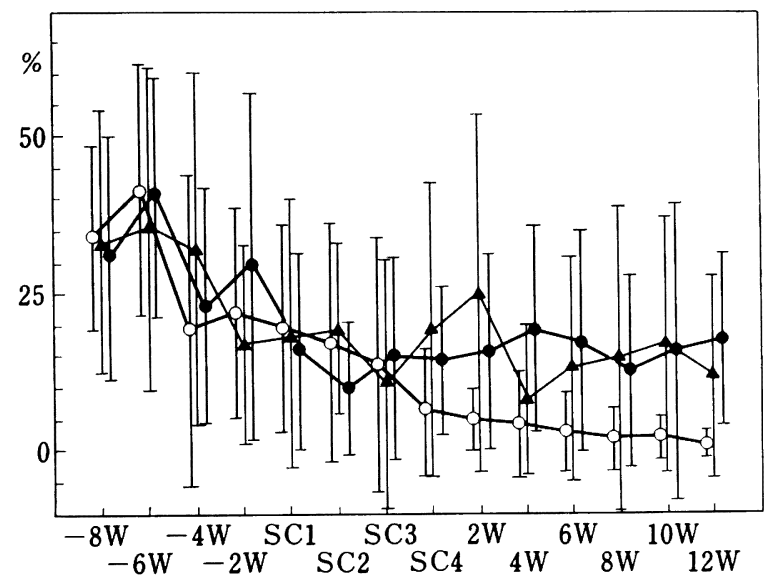

$$
\begin{gathered}
\text { TEST GROUP } \\
(\text { GCF }<50) \\
- \text { TEST GROUP } \\
(\text { GCF } \geqq 50) \\
\_ \text {CONTROL } \\
\text { GROUP } \\
(M E A N \pm S D)
\end{gathered}
$$

SC : SCALING

$\mathrm{W}:$ Weeks

図 4 Black pigmented Bacteroides の比率の経時的变化

90.6 とほとんど変わらず高い值を示し, 処置終了 後 2 週から12週までの経時的な変化に有意差はみ られなかった。

\section{4. probing pocket depth の経時的変化}

図 2 に probing pocket depth の経時的変化 を示す。処置開始時 0 週の時点での平均値は予後 良好群 5.3 , 予後不良群 $6.1 \mathrm{~mm}$ であり GCF 量 の変化と類似していて, Baseline の時点で歯周 ポケットが深いほらが予後が良くない傾向を示し
た。処置後は12週までに減少し，12週の時点で予 後良好群では $2.7 \mathrm{~mm}$, 予後不良群では $4.5 \mathrm{~mm}$ を示し, 予後不良群では歯周ポケットの減少は小 さかった。

\section{5. spirochetes の比率の経時的変化}

図 3 に spirochetes の占める比率の経時的変化 を示す。処置開始時 0 週の時点での平均値は予後 良好群 $4.1 \%$, 予後不良群 $16.9 \%$ で GCF 量およ び probing pocket depth の場合と類似してお 


\section{ATTACHMENT LEVEL}

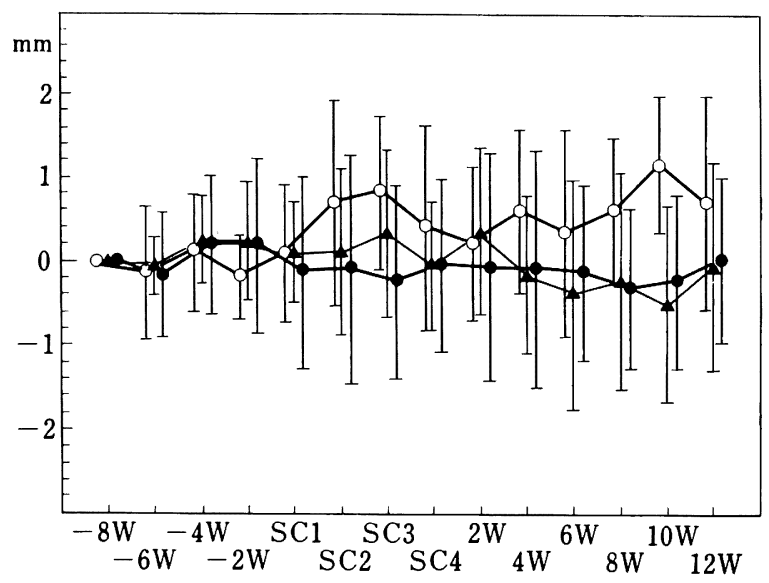

$$
\begin{gathered}
\text { - TEST GROUP } \\
\text { (GCF }<50) \\
- \text { TEST GROUP } \\
\text { (GCF } 250) \\
\_ \text {CONTROL } \\
\text { GROUP }
\end{gathered}
$$

$(\mathrm{MEAN} \pm \mathrm{SD})$

SC : SCALING

W : Weeks

図 5 attachment level の経時的変化

\section{GINGIVAL INDEX}

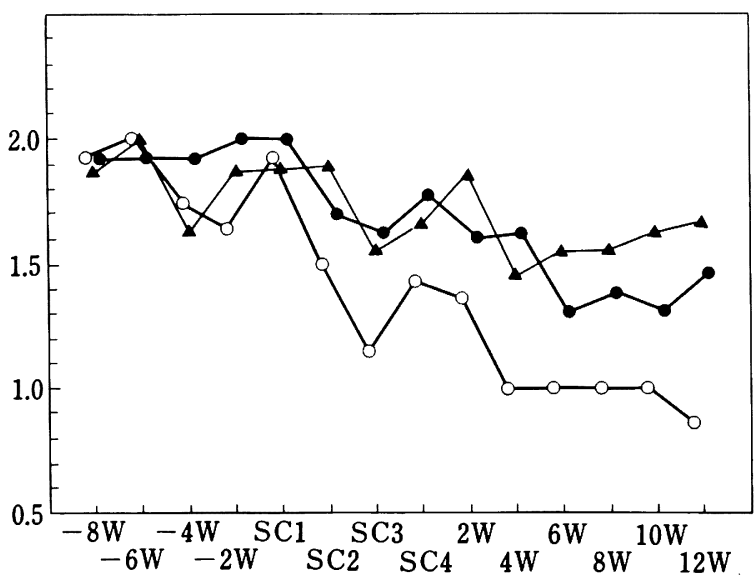

図 6 Gingival Index の経時的変化

り Baseline の時点で spirochetes の比率が有意 に高かった。経時的な変化は GCF 量の変化と類 似していて処置終了後12週までに減少し，12週の 時点では, 予後良好群では $0.3 \%$, 予後不良群で は $2.2 \%$ 示した。

\section{BPB の経時的変化}

図 4 に $\mathrm{BPB}$ の比率の変化を示す。

処置開始時 0 週の時点での平均值は予後良好群 で19.5\%, 予後不良群で16.0\%あり, 経時的な変
化は GCF 量の変化と類似していて, 処置終了後 12週までに減少した。12週の時点では，予後良好 群では $1.1 \%$, と減少していたが，予後不良群で は17.8\%と Base line と変わらず有意の減少は みられなかった。

7. 他のパラメーターの経時的変化

1) attachment level

図 5 K attachment level の経時的変化を示 す。処置開始時 0 週の時点の変化量を 0 とする 


\section{BLEEDING ON PROBING}

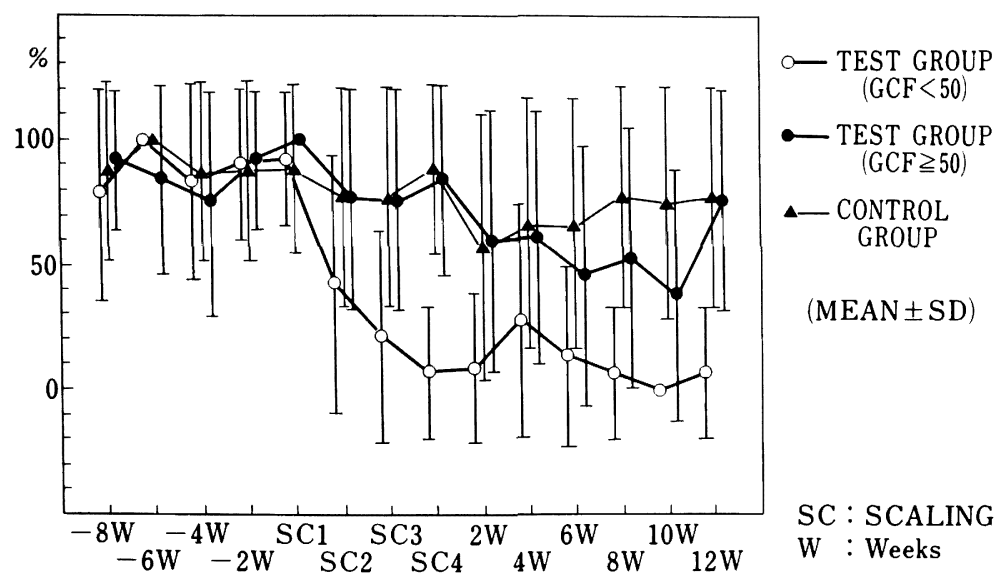

図 7 Bleeding on probing の経時的変化

PLAQUE INDEX

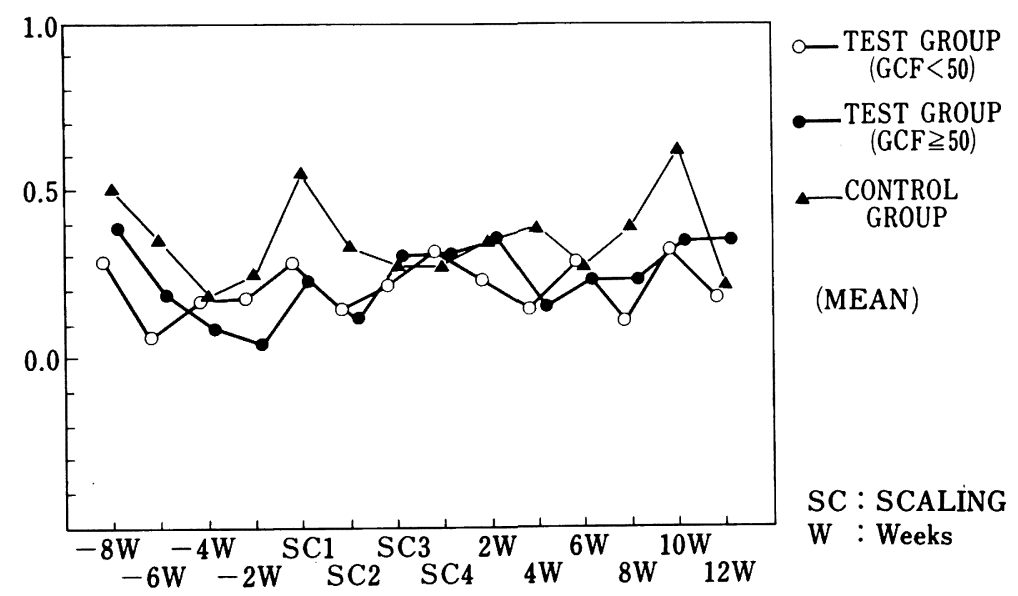

図 8 Plaque Index の経時的変化

之, 処置終了後 2 週の時点の変化量の平均値は予 後良好群で 0.23 , 予後不良群でー $0.05 \mathrm{~mm}, 12$ 週 の時点ではおのおの0.71, $0.04 \mathrm{~mm}$ であった。予 後良好群では処置後 2 週から 12 週後にわたる有意 な attachment level の獲得がみられたが，予後 不良群では有意な attachment level の獲得はみ らなかった。

2) Gingival Index

图 6 に Gingival Index の経時的変化を示す。
処置開始時 0 週の時点での平均值は予後良好群で 1.93, 予後不良群で2.00であった。処置終了後 2 週の時点ではおのおの $1.45,1.60,12$ 週の時点で

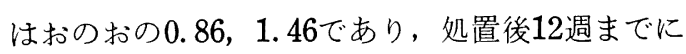
経時的に減少した。しかし, 予後不良群では処置 後 2 週, 12 週とも処置開始時 0 週と比較して有意 な減少はみられなかった。

3) bleeding on probing

図 7 に bleeding on probing の経時的変化を 
TOOTH MOBILITY

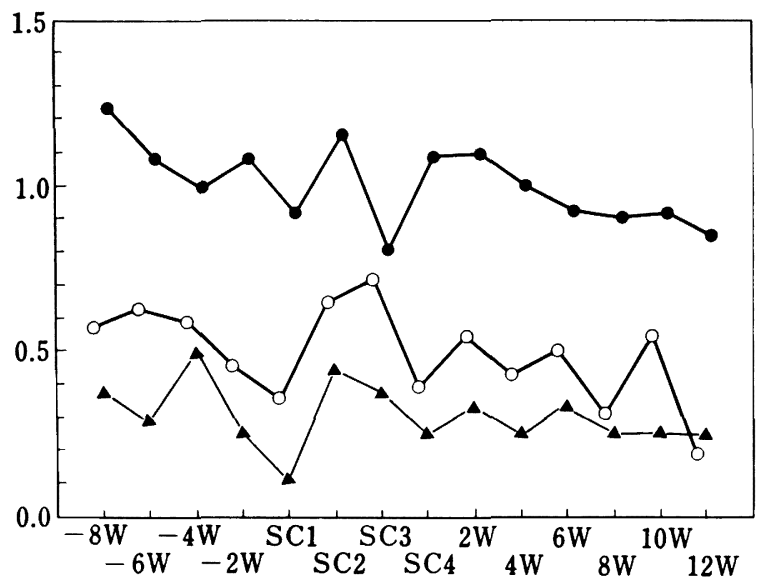

図 9 歯の動摇度の経時的变化

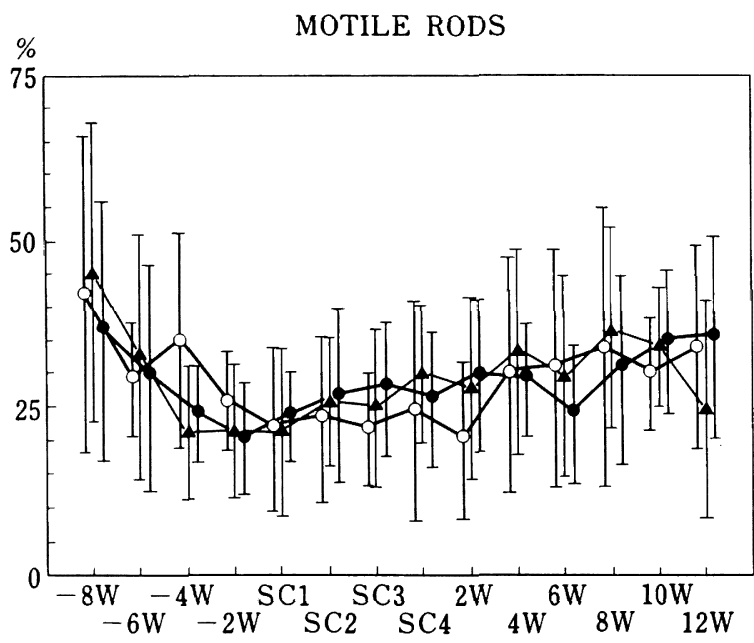

$$
\begin{gathered}
\text {-TEST GROUP } \\
(\text { GCF }<50) \\
\text {-TEST GROUP } \\
\text { (GCF } \geqq 50) \\
\triangle \text { CONTROL } \\
\text { GROUP }
\end{gathered}
$$

$(\mathrm{MEAN} \pm \mathrm{SD})$

SC : SCALING

$\mathrm{W}:$ Weeks

図10 motile rods の比率の経時的変化

示す。処置開始時 0 週の時点での平均值は予後良 好群で $93 \%$, 予後不良群で 100\%であった。処置 終了後 2 週の時点ではおのおの $9 \%, 60 \%$ 之, こ れも有意な差がみられ，予後良好群ではほとんど 歯周ポケット測定時の出血はみられなかった。12

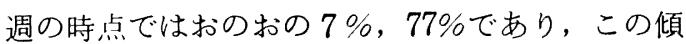
向は持続し, 予後良好群では処置後 12 週までに経 時的に減少した。しかし, 予後不良群では処置終 了後 2 週, 12 週とも処置開始時 0 週と比較して有
意な減少はみられなかった。

4) Plaque Index

図 8 に Plaque Index の経時的変化を示す。 処置開始時 0 週の時点での平均值は予後良好群で

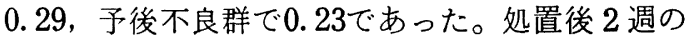
時点ではおのおの $0.23 ， 0.35 て ゙ ， 12$ 週の時点では

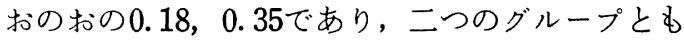
処置終了後12週までに経時的に有意な変化はみら れなかった。 


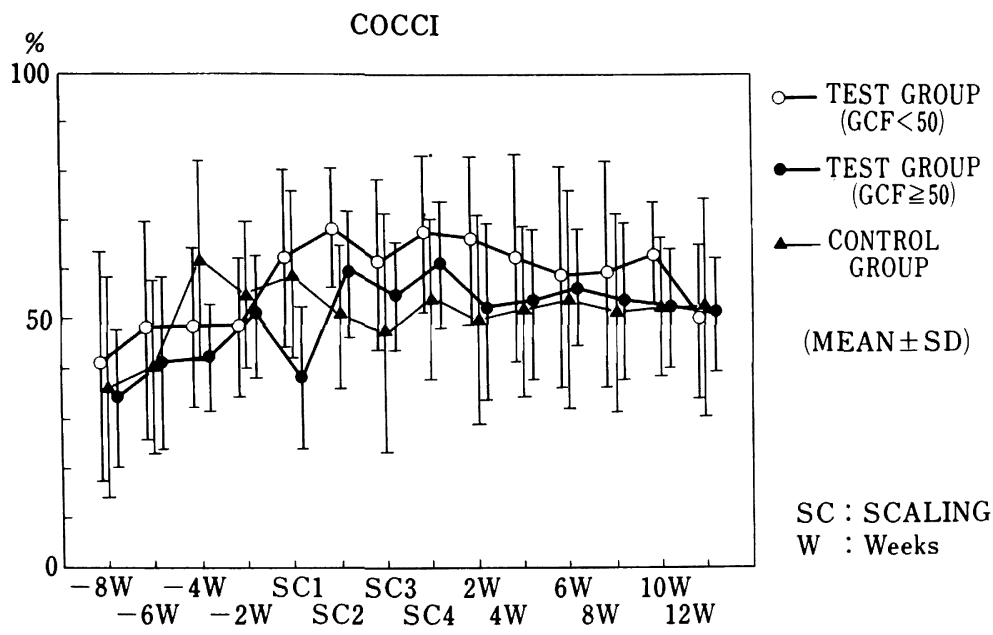

図11 cocci の比率の経時的变化

RODS

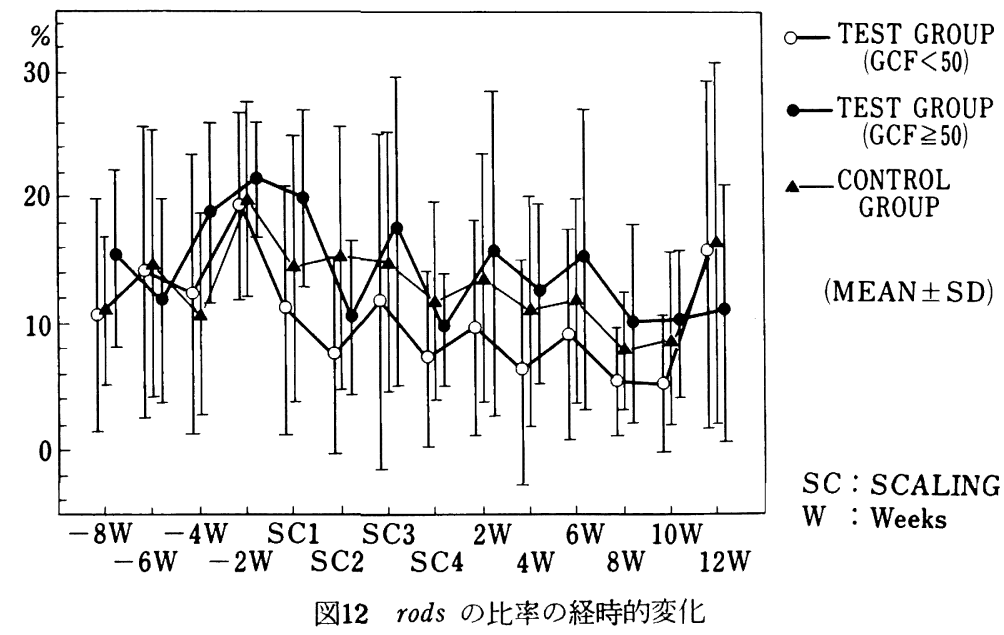

5）歯の動摇度

図 9 に歯の動摇度の経時的変化を示す。処置開 始時 0 週の時点での平均值は予後良好群で 0.36 ,

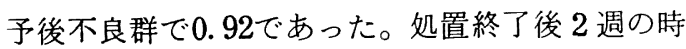
点ではおのおの0.55, 1.10で, 12 週の時点ではお のおの0.18，0.85であり，予後良好群では処置終 了後12週までに有意の減少がみられたが，予後不 良群では処置後12週までに経時的に有意な変化は みられなかった。
6) motile rods の比率

図10に motile rods の比率の経時的変化を示 す。処置開始時 0 週の時点での平均値は予後良好 群で $22.0 \%$, 予後不良群で23.9\%であった。処置 終了後 2 週の時点ではおのおの $20.3 \%, 29.9 \%$

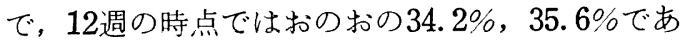
り, 二つのグループとも処置後12週までに経時的 に少し増加する傾向がみられたが, 有意な変化で はなかった。 


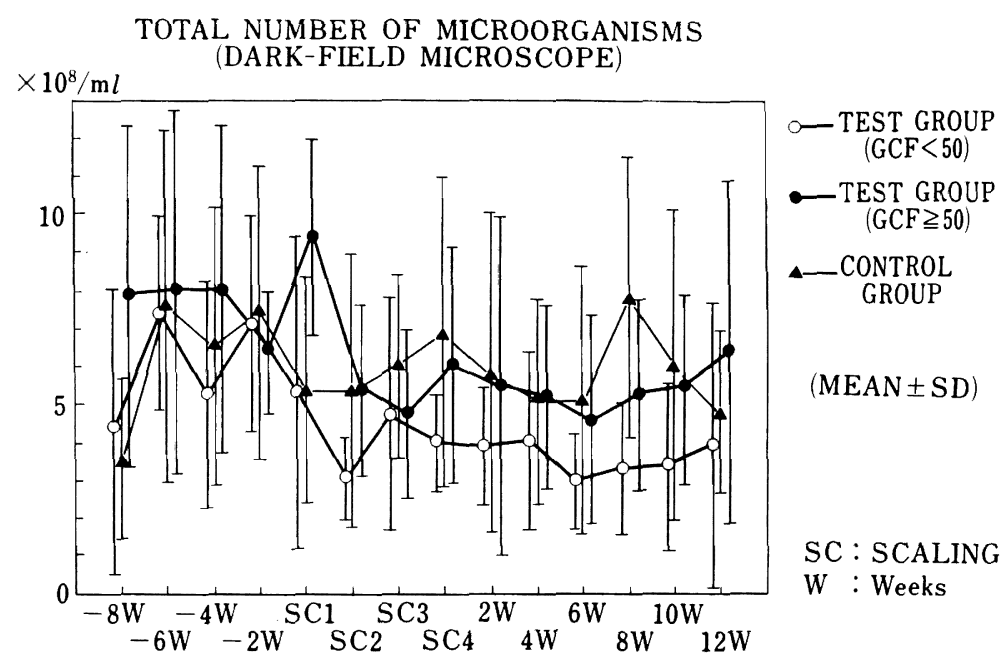

困13暗視野顕微鏡下での観察による総菌数の経時的变化

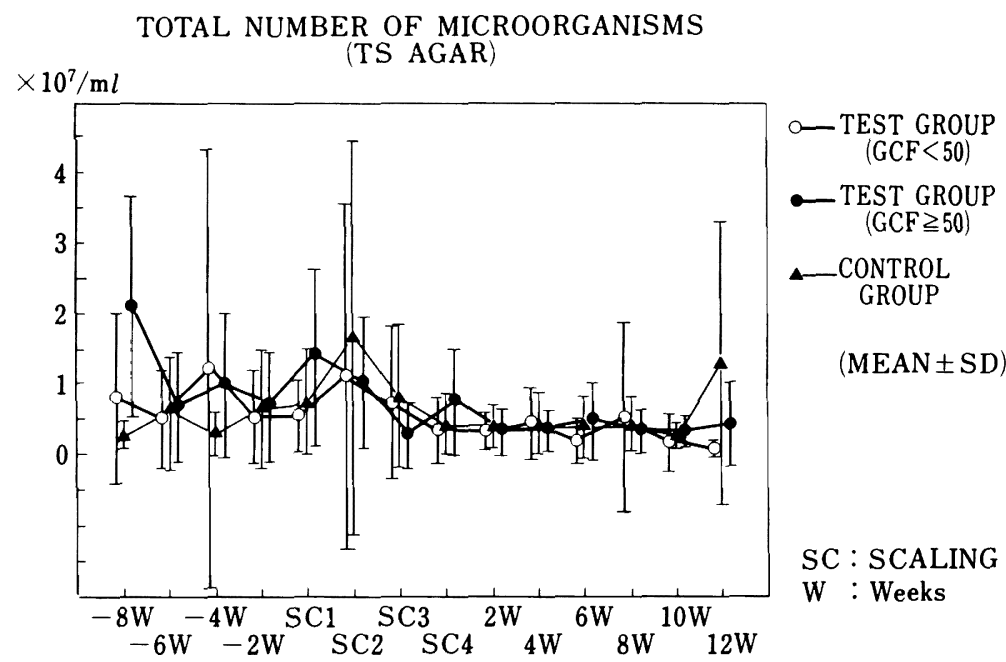

図14 嫌気性菌のコロニー総数 (TS agar) の経時的变化

7） cocci の比率

図11に cocci の比率の経時的変化を示す。処置 開始時 0 週の時点での平均值は予後良好群で 62.6 \%, 予後不良群で $38.4 \%$ であった。処置終了後 2 週の時点ではおのおの51.9\%, 66.7\%で，12週の 時点ではおのおの $49.7 \%, 51.2 \%$ あり, 二つの グループとも処置後12週までに経時的に少し增加 する傾向がみられたが，有意な変化ではなかっ た。

\section{8） $\operatorname{rods}$ の比率}

図12に rods の比率の経時的変化を示す。処置 開始時 0 週の時点での平均值は予後良好群で 11.2 $\%$ ，予後不良群で $20.1 \%$ あっあた。処置後 2 週の 時点ではおのおの $9.9 \%, 15.8 \%$ で，12週の時点 ではおのおの15.7\%，11.0\%であり，二つのグル ープとも処置後12週までに経時的に少し減少する 傾向がみられたが，有意な変化ではなかった。 


\section{A. ACTINOMYCETEMCOMITANS}

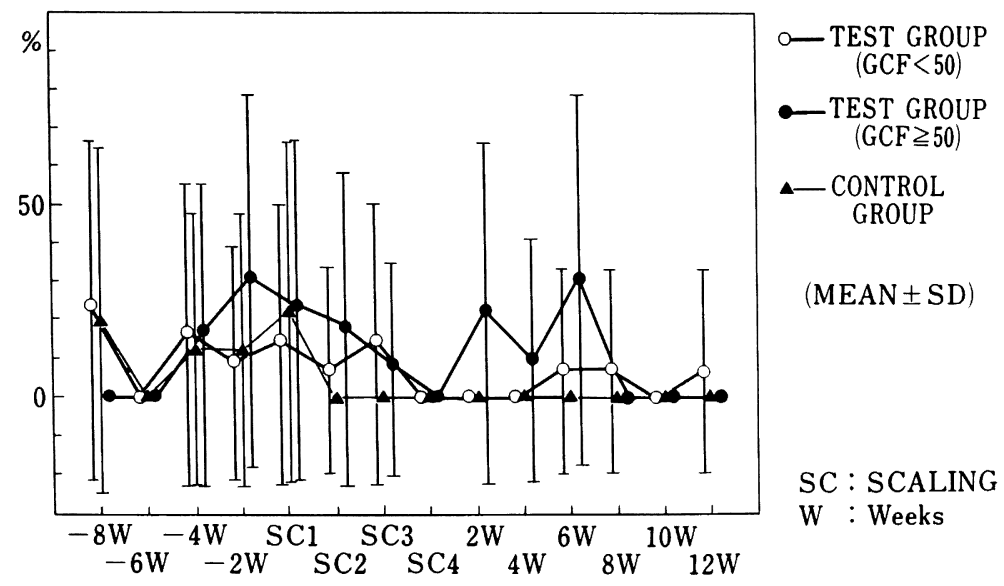

図15 A. actinomycetemcomitans の出現率の経時的変化

9）緿菌数（暗視野顕微鏡下での観察）

図13に総菌数（暗視野顕微鏡下での観察におけ る）の経時的変化を示す。処置開始時 0 週の時点 での平均值は予後良好群で $5.3 \times 10^{7}$ 個 $/ \mathrm{ml}$, 予後 不良群で $9.4 \times 10^{7}$ 個 $/ \mathrm{m} l$ であった。処置後 2 週の 時点ではおのおの $3.9 \times 10^{7}$ 個 $/ \mathrm{m} l, 5.5 \times 10^{7}$ 個/ $\mathrm{m} l$ で, 12 週の時点ではおのおの $3.9 \times 10^{7}$ 個 $\mathrm{m} l$, $6.4 \times 10^{7}$ 個 $/ \mathrm{m} l$ であり, 二つのグループとも処 置後12週までに経時的に少し減少する傾向がみら れたが，有意な変化ではなかった。

10）嫌気性菌コロニ一総数（TS agar 上に形 成された嫌気性菌のコロニ一総数)

図14に嫌気性菌コロ $=$ 総数 (TS agar 上に 形成されたコロニー総数)の経時的変化を示す。 処置開始時 0 週の時点での平均值は予後良好群で $5.6 \times 10^{6}$ 個 $/ \mathrm{m} l$, 予後不良群で $1.4 \times 10^{7}$ 個 $/ \mathrm{m} l$ で あった。処置後 2 週の時点ではおのおの $3.3 \times 10^{6}$ 個 $/ \mathrm{m} l, 3.3 \times 10^{6}$ 個 $/ \mathrm{m} l$ で, 12 週の時点ではおの おの $9.8 \times 10^{5}$ 個 $/ \mathrm{m} l, 4.5 \times 10^{6}$ 個 $/ \mathrm{m} l$ であり, 二 つのグループとも処置後12週までに経時的に少し 減少する傾向がみられたが，有意な変化ではなか った。

11) Actinobacillus actinomycetemcomitans の 比率

図15に Actinobacillus actinomycetemcomitans $の$
比率の経時的変化を示す。処置開始時 0 週の時点 での平均值は予後良好群で14. $0 \%$, 予後不良群で 23. $0 \%$ であった。処置後 2 週の時点ではおのおの $0 \%, 22.0 \%$ で，12週の時点ではおのおの7.0\%， $0 \%$ あり, 二つのグループとも処置後 12 週まで に経時的な変化は一定していなかった。

\section{IV. 考察}

一般に初期治療後の臨床的評洒としては, 歯周 ポケットの深さの減少, アタッチメントレベルの 獲得, プラーク付着状態の減少, 雪肉の炎症症状 の軽減, プロービング時の出血の消失, 歯の動摇 の軽減などの臨床状態の改善が, これまで評価の 刘象となっていた。

歯周ポケット内の状態の変化については, 検査 が煩雑であるため現在のところ詳しく調べられた 報告は少ない。そこで, これまでの初期治療後の 臨床状態の改善について, 臨床的および細菌学的 パラメーターの変化の両面からさまざまな報告が 積み重㸚られてきている。

1. probing pocket depth, 歯肉溝浸出液量 (GCF 量), spirochetes の比率, Black pigmented Bacteroides (BPB) の比率の変化について

1) probing pocket depth について 初期治療後の probing pocket depth の変化 
についての報告も多様である。Hinrichs ら ${ }^{8)}$ の研 究では, 中等度から重度に進行した歯周炎患者19 名の76部位（上顎符 2 小曰歯および第 1 大曰歯に 存在する $4.5 \mathrm{~mm}$ 以上の霜周ポケット) に対して 麻酶下でスケーリング・ルートプレーニングを行 った場合，術前 $5.65 \pm 0.22 \mathrm{~mm}$ の歯周ポケット が術後 $4 \sim 6$ 週で $3.19 \pm 0.20 \mathrm{~mm}$ に改善された。 Hakkarainen 591 ${ }^{9}$, 14人の歯周炎患者の $6 \mathrm{~mm}$ 以上の深さの歯周ポケット48部位に対して麻酔下 でスケーリング・ルートプレーニングを行ったと ころ, 術前で $8.3 \pm 0.3 \mathrm{~mm}$ であったが 30 日後に は $5.6 \pm 0.3 \mathrm{~mm}, 120$ 日後には $5.0 \pm 0.3 \mathrm{~mm}$, 210 日後には $4.5 \pm 0.3 \mathrm{~mm}$ と改善したことを示し た。Müller ら ${ }^{10)}$ の報告では, 中等度から重度に 進行した 10 人の歯周炎患者の $5 \mathrm{~mm}$ 以上の深さの 歯周ポケット36部位に対して麻酔下でスケーリン グ・ルートプレーニングを行った場合, 浅い歯周 ポケット $(5 \sim 6 \mathrm{~mm})$ では術前 $5.8 \pm 0.4 \mathrm{~mm}$ か 5 2 力月後には $3.5 \pm 0.8 \mathrm{~mm}, 6$ 力月後には 3.2 $\pm 1.0 \mathrm{~mm}$ と減少し, 深い霜周ポケット $(7 \mathrm{~mm}$ 以上）では術前 $8.3 \pm 1.1 \mathrm{~mm}$ から 2 力月後には $4.5 \pm 1.3 \mathrm{~mm}, 6$ 力月後には $4.5 \pm 1.4 \mathrm{~mm}$ であ った。Walsh ら ${ }^{11)}$ の研究によると, 成人性蒾周 炎患者 6 人の $5 \mathrm{~mm}$ 以上の菊周ポケットに対して 麻醉下でスケーリング・ルートプレーニングを行 ったところ, 術前で $6.10 \pm 1.70 \mathrm{~mm}$ であったが， 術後 1 力月で $4.20 \pm 1.10 \mathrm{~mm}, 3$ 力月で $4.40 \pm$ $1.10 \mathrm{~mm}$ と有意に減少した。

Van Winkelhoff ら ${ }^{12)}$ の報告では，8 人の成人 性紫周炎患者の $6 \mathrm{~mm}$ 以上の深さの歯周ポケット 32部位にスケリング・ルートブレーニングを行っ た場合, 術前で $7.2 \pm 0.7 \mathrm{~mm}$ であったが, 術後 2 週では $6.0 \pm 0.8 \mathrm{~mm}, 8$ 週では $5.7 \pm 0.6 \mathrm{~mm}$ と改善した。Lavanchy ら ${ }^{18)}$ は, 中等度から重度 の歯周炎患者 7 人の $6 \mathrm{~mm}$ 以上の深さの歯周ポヶ ット14部位を含む全顎にスケーリング・キュレッ タージを行った場合, 術前 $6.9 \pm 0.8 \mathrm{~mm}$ であっ たが, 術後70日には $4.6 \pm 0.2 \mathrm{~mm}$ と改善したと 報告した。Silverstein ら ${ }^{14)}$ の研究では，7人の 中等度の雨周炎患者の 7 部位の歯周ポケットにス
ケーリング・ルートプレーニングを行ったとこ ろ, 術前で $5.19 \pm 0.67 \mathrm{~mm}$ であったが, 術後 2 週 では $5.17 \pm 0.68 \mathrm{~mm}, 4$ 週では $4.19 \pm 0.74 \mathrm{~mm}$, 8 週では $4.17 \pm 0.70 \mathrm{~mm}$ と改善された。

Loos ら ${ }^{15)}$ は, 11 人の菌周炎患者の $5 \mathrm{~mm}$ 以上 の深さの歯周ポケットで分岐部病変を含まない切 歯および小田歯24部位とII 級の分岐部病変を含む 31部位について麻酔下でスケーリングを行ったと ころ, 大臼歯部では術前で $7.0 \mathrm{~mm}$ であったが術 後12週では $5.6 \mathrm{~mm}, 52$ 週では $6.2 \mathrm{~mm}$ となり, 切歯および小白歯部では術前で $7.3 \mathrm{~mm}$ であった が, 術後 12 週では $4.9 \mathrm{~mm}, 52$ 週では $5.2 \mathrm{~mm}$ と 改善した。

Renvert ら ${ }^{16)}$ の報告によると，16人の歯周炎患 者の $6 \mathrm{~mm}$ 以上の歯周ポケット 111 部位にスケー リング・ルートプレーニングを行ったところ，術 前の $8.0 \mathrm{~mm}$ から 6 力月後には $5.8 \mathrm{~mm}$ と減少し た。

私達が今回初期治療を行った $5 \mathrm{~mm}$ 以上の深さ の朄周ポケット27部位については, probing pocket depth 4 歯を除いて術後12週で減少してい た。術前では 5 〜 $\mathrm{mm}$ であったが, 術後 12 週で は2〜6 mm と改善した。この結果は, Hinrichs $5^{8)}$, Müller $5^{10)}$, Walsh $5^{11)}$, Silverstein ら ${ }^{14)}$ の研究結果と類似していた。

2) GCF 量について

歯周の炎症症状を表す指標の一つとして，歯肉 溝浸出液量 (GCF 量) の定量を行らがこの変化 についての報告も多様である。Tsuchida ら ${ }^{17)}$ 10人の歯周炎患者にスケーリングおよびキュレッ タージを行い 108 部位について GCF 量を GCF メーター（HAR 600）を用いて定量したところ, 術前と比較し術後 4 週目では GCF 量は有意に減 少したこと，また GCF 量は Gingival Index お よび probing pocket depth と有意の相関があっ たことを報告した。Armitage ら ${ }^{18)}$ の研究では， 60 人の軽度から中等度の歯肉炎および中等度の歯 周炎患者の GCF 量を Periotron ${ }^{\circledR}$ (Harco) を用 いて定量したところ，GCF 量は spirochetes の 比率と有意の相関が得られた。Hinrichs $5^{8)}$ は, 
ペーパーストリップスで採取した GCF をニン ヒドリンで染色して定量したところ，術前に 4.5 $\mathrm{mm}$ 以下であった部位では $6.77 \pm 0.93 \mathrm{~mm}$ から 術後 $4 \sim 6$ 週で $4.19 \pm 0.86 \mathrm{~mm}$ と有意に減少し たが，術前に $4.5 \mathrm{~mm}$ 以上であった部位では 9.12 $\pm 1.55 \mathrm{~mm}$ から術後では $8.50 \pm 1.68 \mathrm{~mm}$ と有意 な変化はみられなかったと報告しだ。Hakkarainen ら ${ }^{9)}$ は, GCF の 3 分間での流速を測定した ところ, 術後 30 日では, $1.8 \mathrm{~mm} / 3 \mathrm{~min}$. で 120 , 210 日経過しても有意な減少はみられず, 210 日 後の流速は $1.4 \mathrm{~mm} / 3 \mathrm{~min}$. であったことを示し た。Müller ら ${ }^{10)}$ の研究では, GCF の 3 分間での 流速を測定したところ, 術前では $1.2 \pm 0.9 \mathrm{~mm} / 3$ min. で, 術後 2 力月では $1.0 \pm 1.0 \mathrm{~mm} / 3 \mathrm{~min}$. と有意に減少したが， 6 力月後では $1.2 \pm 1.1 \mathrm{~mm} /$ $3 \mathrm{~min}$. と術後の状態に後戻りを示した。

Van Oosten ら ${ }^{19}$ の研究では, 11人の慢性炎症 性歯周炎患者の 6〜 $7 \mathrm{~mm}$ の深さの歯周ポケット 22部位の GCF 量を Periotron ${ }^{\circledR}$ (Harco) を用い て定量し血清で測定值を換算したところ，術前で は probing pocket depth が $6(5 \sim 8) \mathrm{mm}$ で GCF 量は $0.09 \sim 0.3 \mu l$ (平均 $0.11 \mu l$ ) で, スケーリング・ルートブレーニング後 3 力月では probing pocket depth が $4(2 \sim 7) \mathrm{mm}$ で GCF 量は $0 \sim 0.4 \mu l$ (平均 $0.12 \mu l$ ) を示し, 有 意の減少はみられなかった。Biagini ら20)は, 12 人の成人性歯周炎患者について GCF 量を Periotron 6000 (Harco) を用いて定量し， 5 人の Biopsy から電子顕微鏡を用いて組織学的観察を 行い比較したところ, 術前で 95〜199 ペリオト口 ンュニットを示した 5 部位で, キュレッタージ後 30〜60日ですべての部位で50ペリオトロンユニッ 卜以下となったこと, また GCF 量の減少は組織 学的な炎症症状の緩解と有意に相関したことを報 告した。Silverstein ら ${ }^{14)}$ の研究では, Periotron $6000 ®$ を用いて GCF 量を定量したところ，術前 では $20.29 \pm 7.59$ ペリオトロンュニットであった

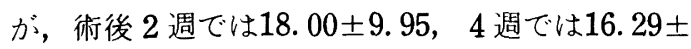
4.27 , 術後 8 週では $20.57 \pm 7.48$ と術後 2 週目の 測定值を除いて有意の減少はみられなかった。
GCF 量の定量は, GCF の採取法や定量法にさ まざまな方法がある。現在最も多く用いられるの は Periotron®による定量法である。私達もこの 方法を用いたが，得られた結果は Biagini ら20)の 報告と類似していた。

3) spirochetes および Black pigmented Bacteroides (BPB) の比率について

初期治療を行った場合の細菌学的変化として, 顕微鏡下で観察した spirochetes の比率や嫌気培 養下での BPB の比率についての報告が多くみら れる。Listgarten られの研究によると，12人の 進行した幽周炎患者の比較的健康な部位と病変が 進行した部位の細菌学的検索を暗視野顕微鏡下で 行ったところ, spirochetes の比率は健常な部位 の蒾肉溝 $(1.9 \pm 0.1 \mathrm{~mm})$ では $1.8 \pm 0.9 \%$ であっ たが, 病気が進行した部位での歯周ポケット (7.3 $\pm 0.4 \mathrm{~mm}$ ) 内では $37.7 \pm 2.8 \%$ であった。Hinrichs らクは, 麻酔下でスケーリング・ルートプ レーニングを行ったところ, 歯周ポケットの深さ が $4.5 \mathrm{~mm}$ 以下の場合には, spirochetesの比率は $10.11 \%$ から術後 4 〜 週で $2.88 \%$ と有意に減少 したが, BPB 比率は術前 $5.05 \%$, 術後 $2.02 \%$ と 有意な変化はみられなかったこと, 歯周ポケット の深さが $4.5 \mathrm{~mm}$ 以上の場合にも, spirochetes の 比率は術前で $20.95 \%$, 術後には $3.14 \%$ と有意に 減少したが, BPB の比率は術前で $14.0 \%$, 術後 には $9.72^{\circ}$ 。と有意な変化はみられなかったことを 示した。Slots ら 211 は, 中等度から重度に進行し た歯周炎患者 20 人の 142 部位について位相差顕微 鏡下での観察と培養による細菌学的研究を行い, 術前と初期治療後 $3 ， 6 ， 12$ 力の状態を比較し た場合 spirochetes と B. gingivalis の比率とアタ ッチメントロスの間に強い相関が欢られたこと， $3 \sim 6$ 力月後に $2 \mathrm{~mm}$ 以上のアタッチメントの獲 得がみられた部位では spirochetes と B. gingivalis の比率はおのおの13〜43\%，1〜17\%であったこ と, 歯周治療は歯周ポケット中に spirochetes と B. gingivalisがみられなくなるまで行らべきであ ると報告した。MacPhee ら 22 の研究では，41人 の患者の 883 部位について spirochetes と motile 
rods の比率々 probing pocket depth, gigival index, bleeding index の関係について検索した ところ, $3 \mathrm{~mm}$ 以内の浅い歯周ポケットではspirochetesの比率は $3.7 \%, 6 \mathrm{~mm}$ の深さの柬周ポ ケットでは $19 \%$ であり，G. I. が $0 \sim 1$ の場合に は6.1\%, G. I. が $2 \sim 3$ の場合には $12.7 \%$, Bleeding がみられない場合には $2.1 \%$ みられた場 合には9.8\%。であった。 Müller ら ${ }^{101}$ は, spirochetesの比率については, $5 \mathrm{~mm}$ 以上の歯周ポケ ットでは術前に35. $1 \pm 15.3$ 。であったが, 術後 2

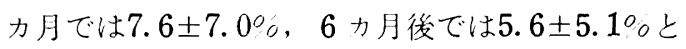
有意に減少したことを示した。Walsh ら11は，

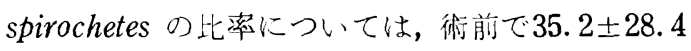
$\%$ であったが，術後 1 力月では $6.1 \pm 12.4 \% 。 ３$ 力月では $13.3 \pm 22.4 \%$ であり, BPB の比率につ いては，術前では $16.50 \pm 14.80 \%$ であったが， 術後 1 力月では $1.94 \pm 3.40 \circ$ であり， 3 力月で は2.10土7.20\%。゙あったことを報告した。Van Winkelhoff ら ${ }^{12)}$ の研究では, $6 \mathrm{~mm}$ 以上の歯周 ポケットでは, spirochetes の比率については術前 で $23.7 \%$ であったが, 術後 2 週では5.9\%，8週 では11. $8 \%$ と少し後戻りしたが有意に減少したこ と, B. gingivalisの比率については, 術前で28.3 \%であったが，術後 2 週では $8.4 \% ， 8$ 週では8.9 $\%$ と有意に減少し，B. intermedius の比率につい ては, 術前では, $2.9 \circ$ 。であったが, 術後 2 週で は4. 3\%，8週では6.7\%。と有意に増加した。Silverstein $ら^{14)}$ は, 術前に比較すると術後 2,4 , 8 週では, coccoid cell の比率は有意に增加した が, spirochetes と motile rodsの比率は有意に減 少したこと, 特に spirochetes の比率について

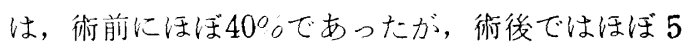
〜 6\%に減少したことを報告した。Harper ら 23 は, 16 人の患者の $6 \mathrm{~mm}$ 以上の深さの菠周ポケッ ト61部位について初期治療前後の臣床症状と Biopsy による組織学的な変化を比較したところ, probing pocket depth と BPBの比率は結合組 織の炎症状態と有意に相関していたこと, そして B. gingivalis は深い歯周ポケットの治療後の治癒 を遲らせている可能性が大きいことが示唆される
と報告した。Loos ら ${ }^{24)}$ の研究によると, 重度に 進行した歯周炎患者 15 人について歯肉縁上のプラ ークコントロールを12週間行い, 12週目にスケー リング・ルートプレーニングを行ったところ， spirochetes の比率については12週目までは変化せ ず16〜28\%であったが，スケーリング・ルートプ レーニング後 1 週で $3 \sim 4 \%$ と有意に減少したこ と, $\mathrm{BPB}$ の比率についても 12 週までは変化せず 19〜36\%であったが，術後 1 週では 3〜10\%と有 意に減少したこと，B. gingivalisの比率について も16〜32\%であったものが，2４％と有意に減 少していた。

今回の私達の結果は, Hinrichs $5^{8)}$, Müller $5^{10)}$, Walsh $5^{11)}$, Van Winklehoff $ら^{12}$, Silverstein ら ${ }^{14)}$ の研究結果と類似していた。す なわち, スケーリング・ルートプレーニング前後 の臨床症状の変化と細菌学的な変化について評価 したところ, 臨床症状の変化としては probing pocket depth および GCF 量の二つのパラメ 一ター, 細菌学的な変化としては spirochetes と $\mathrm{BPB}$ の比率の二つのパラメーターの変化が著し いことが認められた。そしてこれらのパラメータ 一の減少が大きかった部位と，それよりも小さか った部位の二つのグループに分けられると考えら れた。そこで，処置後12週での測定值を基準にし て GCF 量および probing pocket depthの減少 がみられ， spirochetes の比率が $3 \%$ 以下であり， BPB の比率が $10 \%$ 以下であるといら条件をすべ て満たす部位を治瘾が良好であったグループ（予 後良好群), その他の部位を治癒が良好でなかっ たグループ（予後不良群）とした。この二つのグ ループは, GCF 量についてみると50ペリオトロ ンュニットで分けられた。

臨床症状の中で歯肉の炎症状態を示す指標とし て GCF 量を用いたが，現在までに最も多く用い られているのは bleeding on probing である。 初期治療後, bleeding on probing の比率は減少 すること, そしてこの bleeding on probing は spirochetes の比率と相関することが報告されてい $ろ^{25,26)}$ 。GCF 量も spirochetes の比率と相関する 
が, bleeding on probingのほうが強い相関を示 したことも報告されている9”。実際に臨床で簡便 に使用しやすいのは bleeding on probing であ るが, probing の際の圷力の強さや雬周ポケット 底部の組織の炎症状態などにより測定値が左右さ れやすいし, 出血の有無といら指数の性格上, 炎 症状態を詳細に把握するのは難しいと考えられ る。GCF 量の測定は, 測定器の改良により簡便 に定量しやすくなった。これにもぺー・゚ーストリ ップスを挿入する部位を一定させることが難しく ストリップスの幅が広いので挿入できる部位が限 られるといら久点はあるが，歯周ポケット内の炎 症状態を bleeding on probing よりも定量的に 知ることができる。組織学的な研究からも, $\mathrm{GCF}$ 量は歯肉組織の炎症状態と正の相関を示寸 ことが確認されている。今回の結果からも, スケ ーリング・ルートプレーニング後の治癒状態を判 定する要因として GCF 量の減少が強く関係して いると考えられる。

細菌学的なパラメーターとして spirochetes と BPB の比率に注目した。これは, 暗視野顕歪鏡 下で spirochetes は形態的に識別しやすく, その比 率の変化を把握しやすいためである。 motile rods については，その運動性から動きが速い場合も遅 い場合も識別する際に誤差を生じやすい。BPB の比率は嫌気培養後のプレート上で黒色のコロニ 一を作るため判別しやすく, その比率の変化を追 求しやすい。また分離培養にはより多くの時間を 要するが, BPB は培養後 1 週間で十分確認しう ることから選択した。これらの四つのパラメータ 一の変化を観察したとき, 二つの臨床的パラメー ターの変化は二つの細菌学的パラメーターの変化 と関係があり, 特に GCF 量の変化は他の三つの パラメーターの変化とよく相関していたこと,さ らにこの変化はスケーリング・ルートプレーニン グ後 2 週ですでに現れ, その平均值は50ペリオト ロンュニット以下であることが今回の研究で示さ れた。

2. 他のパラメーターについて

1) attachment level について
Bardersten ら ${ }^{27}$ の研究に上机ば，49人の被験 者の切迷，小臼雨 1,688 部位について 24 力月間推 察したところ, 術前の probing pocket depth が大きい注ど, 初期治療後の attachment level の獲得がみられる可能性が大きかった。また， Badersten ら ${ }^{28)}$ は, 39 人の被験者の切歯，小四歯 部 1,956 部位について初期治療後 5 年間観察した ところ, plaque score, bleeding score も attachment loss が引き起こされる可能性を予知する確 率は約30\%であったが，残存する歯周ポケットが $7 \mathrm{~mm}$ 以上の場合には約 $50 \%$ であり, 歯周ポケッ

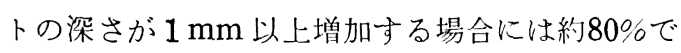
あったと報告した。Claffey ら 29 は，17人の患者 の 2,121 部位について初期治療後 3 年 6 力月間観 察を行ったところ, 歯周ボケットの樑さの増加が あって bleeding on probing の比率が高い場合 には attachment loss が引き起こされる可能性 が大きいことを示唆した。Slots ら ${ }^{21)}$ は，初期 治療後の attachment loss は B. gingivalis と spirochetes の比率と大きく関係していることを 報告した。今回の私達の結果でも, 初期治療後の spirochetes の比率が $3 \%$ 以下で, BPB の比率が 10\%以下であった部位 (予後良好群)では attachment の獲得がみられたことから, attachment の獲得は spirochetes と BPB の比率の減少と関 係があると考觉られた。

2) Gingival Index, Bleeding on probing $に$ ついて

予後良好群では術後 2 週の時点で GCF 量の変 化と同様に既に Gingival Index, bleeding on probing の改善がみられた。そして GCF量, G. I. bleeding on probing の変化は類似していた。 Engelberger $ら^{30}$ は, GCF 量と Papillary Bleeding Index および Sulcus bleeding Index と の間に相関があったこと, Nowicki ら ${ }^{311}$ は, bleeding time と GCF 量の間に相関があった こと, Hirsch ら ${ }^{32)}$ は, GCF 量と bleeding on probing との間に関係があったことを報告した。

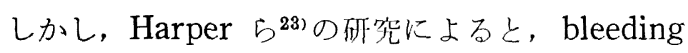
on probing 之歯肉結合組織の炎症状態の間には 
有意な相関はみられなかった。

3) Plaque Index について

Plaque Index は, 実験期間を通じて初期治療 を行った部位と対照部位の間で有意な差はみられ なかった。Lavanchy ら ${ }^{13)}$ は, スケーリング・ル ートプレーニング後70日での畨周ポケット内の細 菌学的変化は歯肉縁上のプラークコントロールの 程度に影響されなかったことを示した。

Loos ら ${ }^{24)}$ は, 歯肉縁上のプラークコントロー ルの状態は12週間の口腔衛生指導期中の蒾周ホケ ット内の細菌の組成に有意の変化を与えなかった こと,ささに12週目のスケールリングルートプレ 一ニング後 1 週での歯周ポケット内での spirochetes の比率および B. gingivalis の比率の変化 に影響を及ぼさなかったと報告した。

\section{4）歯の動摇度}

歯の動摇度については, 術前の予後良好群およ び対照部位と予後不良群との間に有意な差が認め られた。予後不良群では, 予後良好群および対 照部位よりも歯の動摇度は大きかった。術前の probing pocket depth についても, 予後不良群 は予後良好群よりも大きい傾向がみられたことか らも, 米周組織の炎症の程度と残存支持組織量に 有意の差があったと考えられた。Ramfjord ら33 も，歯の動摇度の增大は必ずしも咬合性外傷によ るものではなく，それは歯槽骨の吸収によるもの であると述べている。術前に歯の動摇度が小さく 雨槽骨吸収が軽度であると考えられる部位は, ス ケーリング・ルートプレーニング後に治瘾する可 能性が大きいことが示唆された。

\section{5) motile rods の比率}

初期治療後の motile rods の比率は有意に減 少することが知られている (Rosenberg ら ${ }^{34)}$, Singletary $ら^{35)}$, Magnusson $5^{36)}$ )。私達の結果 でも歯肉縁上のプラークコントロール後有意に減 少し, スケーリング・ルートプレーニング後 2 週 まで持続したが，その後12週まで後戻りする傾向 がみられた。Offenbacher $5^{37)}$ は, 成人性雨周炎 患者 60 人の歯周ポケット内の細菌を暗視野顕微鏡 下で観察し, 小型の運動性球菌および運動性桿菌
がコロニーを形成しはじめると小型の spirochetes が增殖しはじめ, その後フィラメント状の桿菌, 紡鍾状菌と增殖して細菌叢の形成が進さことを示 した。

Sbordone ら ${ }^{38)}$ は, 雨周炎患者 8 人の $5 \mathrm{~mm}$ 以 上の歯周ポケット内の細菌の初期治療後の変化を 術後7日，21日，60日に観察し，実験期間を通じ て motile rods の比率に有意な変化はみられなか ったと報告した。これらの報告からも，歯周ポケ ット内の motile rods の存在は初期治療後の細菌 叢の組成の再形成と密接な関倸をもつと考元られ た。

6) $\operatorname{cocci}$ の比率

Cocci の比率は, 初期治撩後有意偪加するこ とが知られている (Rosenberg ら ${ }^{34)}$, Singletary $\left.ら^{35)}\right)$ 。私達の結果でもスケーリング・ルートプ レーニング後 2 週の時点ですでに有意な增加がみ られた。

7) $\operatorname{rods}$ の比率

Mosques $5^{399}$ の研究では, rodsの比率は初期 治療後 3 日には減少したがその後70日まで有意に 増加した。Greenwell 540) は, 初期治療後 8 週 まで rodsの比率に有意な変化はみられなかった と報告した。Walsh ら $22.2 \%$ あったたが，初期治療後 1 力月では54.0土 $22.7 \%, 3$ 力月後では $40.3 \pm 26.4 \%$ と術後有意に 增加したことを示した。私達の結果では, スケー リング・ルートプレーニング 2 週では減少した が，12週では後戻り傾向がみられた。

8）暗視野顕微鏡下での観察による総菌数,お よび TS agar 上に形成されたコロニー総数 初期治療により顕微鏡下で観察した総菌数や嫌 気性菌コロニー総数が減少したといら報告がある (Van Oosten $5^{19)}$, Loos $5^{15)}, \operatorname{Loos} 5^{24)}$ ) が, 有意な変化はみられなかった，といら報告むある $\left(\right.$ Harper $\left.5^{28)}\right)$ 。今回の結果では, 暗視野顕微鏡 下での総菌数および TS 血液寒天培地上の嫌気性 菌のコロニー総数についてスケーリング・ルート プレーニング後減少する傾向がみられたが，有意 な変化ではなかった。このことから, 初期治療に 
より歯周ポケット内の細菌叢の組成は大きく変化 したが，暗視野顕微鏡下での総菌およびTS 血液 寒天培地上の嫌気性菌のコロニ一総教は大きな変 化を受けなかったと考えられた。

\section{9) A. actinomycetemcomitans の比率}

A. $a$. については, 初期治療によって A. $a$. を 排除することは難しいという報告がある。Renvert ${ }^{16.41)}$ は, 16 人の患者の歯周ポケットの深 さが $6 \mathrm{~mm}$ 以上の 111 部位について観察し, 初期 治療後 6 力月および歯周外科後 3 力月の時点で,

B. gingivalis はほとんと検出されなかったが，

A. $a$. は除去することができなかったことを確認 し，これは $A . a$. が歯肉組織内に侵入しているた めであると示唆した。今回の結果も，A. $a$. の出 現率江初期治療に関係がみら机ず，一定していな かった。

今回, 私達はスケーリング・ルートプレーニン グ後の有効性を予知しらる要因を知るために，臨 林症状を表すいくつかのパラメーターと暗視野顕 微鏡下での観察上培養法による細菌学的パラメー ターを用いて術後 3 力月間検索した。臨床的パラ メーターは, 肉眼的で主観的な判別, probing 時 の王力などにより測定值が影響を受けるためにす べてが客観的な手段とはいえないが，現在までに 臨床上簡便に用いられている方法である。その中 で GCF 量の測定が臨床的に意義をもつことが明 らかになってきた。細菌学的パラメーターについ ても，暗視野顕微鏡下での観察により直接歯周病 原細菌を同定しうるものではなく,培養法も $\mathrm{BPB}$ の比率のみでは Bacteroides の中の特に原因菌 の同定はできない。このよらに本実験で得られた 結果は限られた情報ではあったが，臨床の場で得 られたサンプルを簡便に観察する方法としては適 当であると考えられた。今後は，DNA probe 法 や歯周ポケット内の酵素による細菌の同定法な と，簡便で詳細な情報を得る方法を併せて用いる ことができれば，より明確な結論を得ることが可 能であると思われた。

\section{V. 結 論}

初期治療の有効性を確認しらる因子を知る目的 で, 初期治療後の臨床的パラメーターと細菌学的 パラメーターの変化について 3 力月間観察を行っ た。中等度から重度に進行した歯周炎患者 9 名 （男性 2 名, 女性 7 名, 27 49歳) の $5 \mathrm{~mm}$ 以上 の深さで上下左右の 4 部位に分かれて存在する単 根歯の歯周ポケット36部位を対象とし，そのうち 27 部位を実験部位とし，9部位を対照部位とし た。そして，以下の結果を得た。

1）スケーリング・ルートプレーニングを行っ たところ，4部位を除いたすべての被験部位で齿 周ポケットの減少がみられた。

2）被験部位は, 臨床的評価求上び細菌学的評 価により二つのグループに分けられた。一つのグ ループは予後良好群であり, 囦周ポケットの深さ および GCF 量の減少と, spirochetes と BPBの 比率の減少がみられた。他の一つのグルーブは予 後不良群であり, 歯周ポケットおよび GCF 量, spirochetes と BPB の比率の減少量は前者より小 さい值を示した。

3）二つのグルーブは GCF 量が50ペリオトロ ン・ユニットで分けられた。予後良好群では，術 後 2 週目にすでに GCF 量の平均値は50ペリオト ロン・ュニット以下となり,この状態は 3 力月間 持続した。

4) A. actinomycetemcomitans の出現率は，ス ケーリング・ルートプレーニングにより影響を受 けなかった。

以上の結果から，次の結論を得た。

スケーリング・ルートプレーニングの有効性 は, 歯周ポケットの深さと GCF 量の減少によ。 て判断しらること, スケーリング・ルートプレー ニング後 2 週目にすでに GCF 量の平均值は 50 リオトロンユニット以下の減少を示し，またこの 状態は spirochetes と BPB の比率の減少に関係 していると考えられた。 


\author{
謝辞 \\ 稿を終えるにあたり，本研究に協力いただきました \\ 本学菌学部学生の時松由里子, 己斐紀代野の両名に心 \\ から感謝いたします。また終始ご協力いただきました \\ 第 2 画科保存学教室の先生方にお礼申しあげます。 \\ なお本研究は, 平成 2 年度文部省科学研究費一般 B \\ (No. 02454433) および厚生省科学長寿研究研究費補 \\ 助金 (長寿科学総合研究事業)により行われたことを \\ 付記する。 \\ 本論文の要旨は, 第63回日本歯科保存学会春期総会 \\ （1991年6月20日）において発表した。
}

\section{文献}

1) Loesche, W. J. : Clinical and microbiological aspects of chemotherapeutic agents according to the specific plaque hypothesis. J. Dent. Res. 58 : 2404-2412, 1979.

2) Waerhaug, J. : Healing of the dento-epithelial junction following subgingival plaque control. J. Periodontol. 49:119-134, 1978.

3) Rabbani, G. M., Ash, M. M. and Caffesse, R. G.: The effectiveness of subgingival scaling and root planing in calculus removal. J. Periodontol. 52 : 119-123, 1981.

4) Löe, H. and Silness, J. : Periodontal disease in pregnancy. I. Prevalence and severity. Acta Odontol. Scand. $21: 533-551,1963$.

5) Silness, J. and Löe, H. : Periodontal disease in pregnancy, II. Correlation between oral hygeine and periodontal condition. Acta Odontol. Scand. 22 : 121-135, 1964.

6) Ainamo, J. and Bay, I. : Problems and proposals for recording gingivitis and plaque. International Dent. J. $25: 229-235,1975$.

7) Listgarten, M. A. and Hellden, L. : Relative distribution of bacteria at clinically healthy and periodontally diseased sites in humans J. Clin. Periodontol. $5:$ 115-132, 1978.

8) Hinrichs, J. E., Wolff, L. F., Philstrom, B. L., Schaffer, E. M., Liljemark, W. F. and Bandt, C. L. : Effect of scaling and root planing on subgingival microbial proportions standaedized in terms of their naturally occurring distribution. J. Periodontol. $56: 187-194,1985$.

9) Hakkarainen, K., Asikainen, S. and Ainamo, J. : A 7-month study of sulcular fluid flow in the assessment of healing after debride- ment of deep pockets. J. Periodontol. 57 : 14-19, 1985.

10) Müller, H-P., Hartman, J. and Flores-deJacoby, L. : Clinical alterations in relation to the morphological composition of the subgingival microflora following scaling and root planing. J. Clin Periodontol. 13 : 825-832, 1986.

11) Walsh, M. M., Buchanan, C. I., Newbrun, E., Taggart, E. J., Armitage, G. C. and Robertson, P. B. : Clinical and microbiological effects of single-dose metronidazole or scaling and root planing in treatment of adult periodontitis. J. Clin. Periodontol. $13: 151-$ $157,1986$.

12) Van Winkelhoff, A. J., Van der Verden, V. and De Graff, J.: Microbial succession in recolonizing deep periodontal pockets after a single course of supra and subgingival debridement. J. Clin. Periodontol. $15: 116-$ $122,1987$.

13) Lavanchy, D. L., Bickel, M. and Baehni, P. C. : The effect of plaque control after scaling and root planing on the subgingival microflora in human periodontitis. J. Clin. Periodontol. 14 : 295-299, 1987.

14) Silverstein, L., Bissada, N., ManouchehrPour, M. and Greenwell, H. : Clinical and microbiologic effects of local tetracycline irrigation on periodontitis. J. periodontol. $59: 301-305,1987$.

15) Loos, B., Claffy, N. and Egelberg, J. : Clinical and microbiological effects of root debridement in periodontal furcation pockets. J. Clin. periodontol. $15: 453-463,1988$.

16) Renvert, S., Wikström, M., Dahlén, G., Slots, J. and Egelberg, J. : Effect of root debridement of Actinobacillus actinomycetemcomitans and Bacteroides gingivalis from periodontal pockets. J. Clin. Periodontol. $17: 345-350,1990$.

17) Tsuchida, K. and Hara, K. : Clinical significance of gingival fluid measurement by "Periotron". J. Periodontol. 52:697-700, 1981.

18) Armitage, G. C., Dickinson, W. R., Jenderseck, R. S., Levine, S. M. and Chambers, D. W. : Relationship between the percentage of subgingival spirochetes and the severity of periodontal disease. J. Periodontol. $53: 550-556,1982$.

19) Oosten van, M. A. C., Mikx, F. H. M. and Rennggli, H. H. : Microbial and clinical 
measurements of periodontal pockets during sequential periods of non-treatment, mechanical debridement and metronidazole therapy. J. Clin. Periodontol. 14 : 197-204, 1987.

20) Biagini, G., Checchi, L., Miccoli, M. C., Vasi, V. and Castadini, C. : Root curettage and gingival repair in periodontitis. J. Periodontol. 59 : 124-129, 1988.

21) Slots, J., Emrich, L. L., Genco, R. J. and Rosling, B. G. : Relationship between some subgingival bacteria and periodontal pocket depth and gain or loss of periodontal attachment after treatment of adult periodontitis. J. Clin. Periodontol. 12 : 540-552, 1985.

22) MacPhee, L. T. and Muir, K. F. : Dark ground microscopy in relation to 3 clinical paramenters of chronic inflammatory periodontal disease. J. Clin. Periodontol. 13 : 900904, 1986.

23) Harper, D. S. and Robinson, P. J. : Correlation of histometric, microbial, and clinical indicators of periodontal disease status before and after root planing. J. Clin. Periodontol. $14: 190-196,1987$.

24) Loos, B., Claffey, N. and Crigger, M. : Effects of hygiene measures on clinical and microbiological parameters of periodontal disease. J. Clin. Periodontol. 15 : 211-216, 1988.

25) Greenstein, G. : The role of bleeding upon probing the diagnosis of periodontal disease, A literature review. J. Periodntol. 55 : 684688, 1984.

26) Kalkwarf, K. L., Kaldahl, W. B., Patil, K. D. and Molvar, M. P. : Evaluation of gingival bleeding folowing four types of periodontal therapy. J. Clin. Periodontol. 16 : 601-608, 1989.

27) Bardersten, A., Nilveus. R. and Egelberg, J. : Effect of non-surgical periodontal therapy. (VIII). Probing attachment changes related to clinical characteristics. J. Clin. Periodontol. 14 : 425-432, 1987.

28) Bardersten, A., Nilveus, R. and Egelberg, J. : Scores of plaque, bleeding, suppuration and probing depth to predict probing attachment loss. 5 years of observation following non-surgical periodotal therapy. J. Clin. Periodontol. 17 : 102-107, 1990.

29) Claffey, N., Nylund, K., Kiger, R., Garrett, S. and Egelberg, J. : Diagnostic predictability of scores of plaque, bleeding, suppura- tion and probing attachment loss. $31 / 2$ years of observation following initial periodontal therapy. J. Clin. Periodontol. 17 : 108-114, 1990.

30) Engelberger, T., Heffti, A., Kallenberger, A. and Rateiotschak, K. H. : Correlation among Papilla Bleeding Index, other clinical indicies and histologically determined inflammation of gingival papilla. J. Clin. Periodontol. $10: 579-585,1983$.

31) Nowicki, D., Vogel, R. I., Melcer, S. and Deasy, M. J.: The gingival bleeding time index. J. Periodontol. 52 : 260-266, 1981.

32) Hirsch, R. S., Clarke, N. G. and Toensend, G. C. : The effect of locally released oxygen on the development of plaqueand gingivitis in man. J. Clin. Periodontol. $8: 21-28,1981$.

33) Ramfjord, S. P. and Ash, Jr. M. M. : Significance of occlusion in the etiolngy and treatment of early, moderate and advanced periodontitis. J. Periodontol. $52: 511-517$, 1981.

34) Rosenberg, E. S., Evian, C. I. and Listgarten, M. A. : The composition of the subgingival microbiota after periodontal therapy. J. Periodontol. 52 : 435-441, 1981.

35) Singletary, M. M., Crawford, J. J. and Simpson, D. M. : Dark-field microscopic subgingival bacteria during periodontal therapy. J. Peirodontal. $53: 671-681,1982$.

36) Magnusson, I., Lindhe, J., Yoneyama, T. and Liljberg, B. : Recolonization of a subgingival microbiota following scaling in the deep pockets. J. Clin. Periodontol. 11 : 193-207, 1984.

37) Offenbacher, S., Costopoulos, S. V., Odle, B. M. and Van Dyke, T. E. : Microbial colonization patterns of loosely adherent subgingival plaque in adult periodontitis. J. Clin. Periodontol. 15 : 53-59, 1988.

38) Sbordone, L., Ramaglia, L., Gulletta, E. and Iacono, V.: Recolonization of the subgingival microflora after scaling and root planing in human periodontitis. J. Periodontol. $61: 579-584,1990$.

39) Mosques, T., Llstgarten, M. A. and Phillips, W. : Effect of scaling and root planing on the compositions of the human subgingival microbial flora. J. Clin. Periodontol. 15 : 144-151, 1980.

40) Greenwell, H., Baker, A., Bissada, N., Debanne, S. and Rowland, D. : The effect of Keyes' method of oral hygiene on the 
subgingival microflora compared to the effect of scaling and/or surgery. J. Clin. Periodontol. 12 : 327-341, 1985.

41) Renvert, S., Wikström, M., Dahlén, G., Slots, J. and Egelberg, J. : On the inabillity of root debridement and periodontal surgery to eliminate Actinobacillus actinomycetemcomitans from periodontal pockets. J. Clin. Periodontol. 17 : 351-355, 1990. 